\title{
An Insight into the Challenges Faced by Academic Women with Pre-school Age Children in Academic Life
}

\author{
Gizem Günçavdı, Şöheyda Göktürk, Oğuzhan Bozoğlu* \\ Department of Educational Sciences, Kocaeli University, Turkey
}

Copyright $\bigcirc 2017$ by authors, all rights reserved. Authors agree that this article remains permanently open access under the terms of the Creative Commons Attribution License 4.0 International License

\begin{abstract}
This study aimed to explore the challenges academic women, especially those who were mothers of pre-school age children, went through. The main guiding question of this study was "How do academic mothers with pre-school age children survive in the academia from pregnancy through all the various stages of parenting and motherhood?". This study employed qualitative case study research design. The study was conducted in a faculty of a state university in Turkey. 6 academic women participated in this study based on the selection criteria. Data was collected through open-ended, semi-structured interviews and analysed through thematic analysis. The findings indicated that though academic women in the study valued the experience of being mothers, they were overwhelmed by the workload; lacked administrative support; and suffered from a never-ending struggle to balance between their academic duties and parental responsibilities.
\end{abstract}

Keywords Academic Mothers, Social Gender, Academic Life, Woman Academics

\section{Introduction}

The inequality between women and men can be seen in many different areas of a social life, and education is one of these areas. Even in contemporary age, there is an imbalance between men and women in educational organizations, especially in higher education institutions. This imbalance can be evaluated as the result of social gender. Before explaining what social gender role is, it is better to define what biological sex means. World Health Organization [1] describes it as both biological and physiological features of women and men. On the other hand, World Health Organization [1] defines the 'social gender' as roles, behaviours, activities and qualities which are formed socially and seen as suitable to women or men. When looking at these definitions, it can be said that the imbalance between women and men results from social gender, not biological sex. In their study, Başarır and Sarı [2] says that social gender results in an imbalance due to the artificial structure about participation in social life, using opportunities, access to services, and using sources. Unfortunately, in these aspects, women are usually in the disadvantaged side of the imbalance.

In Turkey, some people have the belief that women should not work, should get married at a certain age (which is after the age of 18), stay at home and take care of her children. Cindoğlu and Toktaş [3] conducted a study on women who graduated from Girls' Institutes between the years 1960 and 1970. In their study, one of the participants emphasized this belief. She told that her uncle was a hodja (a religious teacher) who said to her father that she should not go to school; implied that no good would come from education; and pressured her on getting married, giving birth to children and taking care of them, like many women did. She was even beaten by her father and her uncle since she wanted to go to school. Especially in those years, this belief was very common, and there were many examples similar to this one. While this belief was more common among society in the past, it is rare in today's Turkey. After some years and considerable efforts, women were successful to overcome this bias against them; because it is possible to see that working and participating in social life have such positive impacts on women's lives as economic independence, spending qualified time with children, being respected by their husbands, social security, and being motivated to take care of themselves [3].

Even though women overcame the bias and started to participate more in social life, it can be claimed that there are still some problems that women encounter in their professional life. As in other organizations, women who work in educational organizations face some obstacles relating to their social gender roles; because education system implicitly or explicitly supports patriarchal system and reinforces the social gender roles. Therefore, even educated and working women in the society internalize their social gender roles [2]. With a more heavy workload than many other working women, academic women should face 
the problem of trying to balance their academic studies like giving lectures, publishing articles, attending academic conferences and their social gender roles like doing the laundry, babysitting, doing housework and so on $[4,5]$.

Dependent on the reasons given above, there are many researches which clearly indicate that there are fewer women academicians when compared to their male colleagues, especially in senior positions $[6,7,8,9]$. For example, women made up of 13 percent of professors and 22 percent of associated professors in Finland [8]. In Sweden, women professors made up of 9 percent of whole academy, while in Netherlands this amount is only 5 percent [8]. Edgren [6] indicates that this quite low number of women in academy should be considered as a big problem and some precautions should be taken just like Swedish Higher Education Act did by emphasizing each university's obligation to promote equality between female and male staff not only in education and research, but also in appointments. This should be evaluated as quite important, because Bagilhole and Goode [9] said that the academy became a 'man's world' and women had difficulties to find recommendations for themselves which would help them to promote, find sources which would enable them to do researches. Bagilhole and Goode [9] also emphasized that even universities in United Kingdom should keep and provide statistical records of their staff depending on some features like their gender, ethnicity and marital status to make sure of giving equal opportunities to women and men in academic world, it could not change the situation in favour of women. Another study conducted by Bett [7] in universities of United Kingdom had similar results. This study showed that the number of women who were at senior levels in academy constituted only the quarter of the total number, the male academics who worked at top positions were twice as much as the female academics [7].

The same situation is valid for Turkey, depending on the results of Higher Education Council's (YOK) statistics of 2015-2016 academic year. The statistics show that the total number of female professors is 6626 , while that of males is 15790; total number of female associate professors is 5285 , while that of males is 9738 ; the total number of female assistant professors is 14214, while that of males is 21087 ; the total number of female instructors is 9574 , while that of males is 12278 [10]. Despite these numbers of academics in higher positions in academic hierarchy, the numbers of female and male research assistants are close to each other. The results of YOK's statistics [10] showed that there are 23617 female research assistants and 23759 male research assistants. Research assistants are the staffs in university who have responsibilities to attend $\mathrm{MA}$ and $\mathrm{PhD}$ educations, and to become academics. So, these results can be interpreted as the impact of social gender roles. However, it would be wrong to say that social gender role is the only factor that affects women research assistants to move on their career, because Bagilhole and Goode [9] found in their study that women had difficulties in their academic achievements' being valued, in overcoming to be alienated and marginalized in academy by their male colleagues, in self-promoting their academic works (and in order to do this, they needed male academic support, usually from their Head of Departments), and in asking for help when they needed since it could be seen as a 'weakness' by their male colleagues. Besides, it is possible to say that social gender roles have a big impact on the process of women academics' professional lives.

In the light of these studies, this study aims to define the challenges academic women, especially those who are mothers of pre-school age children, encounter in their professional life, which can result in heavier family roles to women; as it is believed that if these challenges can be defined and a framework can be constructed, some precautions can be taken in order to limit or minimize these challenges and therefore, academic women can participate efficiently and effectively in academic context and they can proceed through their academic life more successfully. So the guiding question of this study is "How do academic mothers with pre-school age children survive in the academia from pregnancy through all the various stages of parenting and motherhood?"

\section{Methodology}

\subsection{Research Design}

This study employs qualitative case study research design. The goal of case study is to analyse one or more cases in terms of context and time within its boundaries [11]. The researcher who will conduct a case study should decide what the case is. Baxter and Jack [12] said that the researcher should ask himself or herself "Do I want to analyse the individual?", "Do I want to analyse the program?", "Do I want to analyse the process?" or "Do I want to analyse the differences between organizations?". In its relation to the main guiding question, this study is a descriptive case study in that it aims to define the present situation for academic women with pre-school age children.

\subsection{The Context and the Participants}

This study is conducted in a faculty of a state university in Turkey. This university was founded in 1992 , so it can be regarded as a new university, which is thought to be more flexible and suitable for academic women when compared to old universities [8]. The university is situated in an industrial city, so many families consist of working parents, and they are nuclear families that do not include grandparents. Thus, academic women with pre-school age children of this university can be taken as members of nuclear families.

The faculty where the study was conducted has 74 academic personnel. Forty-four of them are female, 30 of them are male academics. Among 44 academic women, 15 of them are research assistants, 5 of them are lecturers, 13 of 
them are assistant professors, 10 of them are associate professors and one of them is professor. Having at least one pre-school age children was the basic criteria of this study. Depending on this, six academic women participated in this study. One of them was associate professor, four of them were assistant professor, and one of them was a lecturer.

\subsection{The Researchers}

This study was conducted by three researchers. Two of them were female and worked as academics in the faculty where this study was conducted. One of these researchers was married and had a pre-school age child and she had been working in the faculty for long years as an associate professor. The other female researcher was not married and did not have a child. She had been working in the faculty for three years as a research assistant. Thus, these researchers were insiders and had the opportunity to see how things were going on in the faculty, which helped them observe and analyse the situation deeply. To increase validity and reliability of the study, the third researcher was male and an outsider (an instructor in another higher education institution). Therefore, this selection of researchers from different gender groups and including an outsider allowed the researchers to analyse the data from different perspectives.

\subsection{Data Collection}

The data were collected through open-ended, semi-structured in-depth interviews each of them taking more or less 30 minutes. Each interview was conducted face-to-face with the participants in a private setting where they could feel more relaxed. Data was collected via digital voice recording and interviews were transcribed verbatim from digital recording. All personal identifiers were removed to preserve anonymity and each participant was given a unique identifier number (i.e. A1 stands for the first academician). The interview questions were developed as can be seen in Table 1:

Table 1. Semi-structured interview questions

\begin{tabular}{|ll|}
\hline - & $\begin{array}{l}\text { How did (do) you accommodate your career with the reality of } \\
\text { women's life-family-the family role? }\end{array}$ \\
\hline - & $\begin{array}{l}\text { How do you compare yourself as an academic to your male } \\
\text { colleagues? }\end{array}$ \\
\hline - & $\begin{array}{l}\text { Do you feel interrupted and how do you handle in the interruption } \\
\text { in your career due to having a baby? }\end{array}$ \\
\hline - & $\begin{array}{l}\text { What circumstances (if any) make you choose between upward } \\
\text { mobility or family stability? }\end{array}$ \\
\hline - & $\begin{array}{l}\text { Did you feel any difficulty (both in real sense and psychologically) } \\
\text { to negotiate maternity leave or to decrease course load as a faculty } \\
\text { member or researcher (from pregnancy through all the various } \\
\text { stages of parenting)? }\end{array}$ \\
\hline - & $\begin{array}{l}\text { What kind of support you needed/received from your } \\
\text { administrators and colleagues, husband, family? }\end{array}$ \\
\hline - & $\begin{array}{l}\text { How do you think the culture in academia respond to your need to } \\
\text { balance work and life? }\end{array}$ \\
\hline
\end{tabular}

\subsection{Data Analysis}

For the study, thematic analysis was implemented to identify themes and patterns within the data. Codes and categories such as 'support from parents', 'more workload on women' and 'social gender role' were developed. After the first meeting in which initial codes and categories were developed by each researcher, to ensure the reliability of data, extensive discussions were held among all researchers and remaining transcripts were subsequently reviewed during this process to explore emerging themes. The researchers independently coded all the data and met at periodical intervals to discuss codes, categories, and themes and ensure reliability. Finally, the researchers compared individual analysis and reached consensus over the emerging themes and their contents.

\section{Findings}

From the detailed analysis of the six interviews, two main themes were yielded. These themes were named as (a) support from social environment is a need, and (b) motherhood is demanding for an academic woman. Within each theme, a number of sub-themes were also identified and these are presented in the following table and discussed under main themes.

In the following section, the themes and its related subthemes are presented in the order given in Table 2. After explanation of their meanings, each sub-theme is given examples of participants' original scripts.

Table 2. Main-themes and sub-themes

\begin{tabular}{|c|ll|}
\hline Main themes & \multicolumn{1}{c|}{ Sub-themes } \\
\hline $\begin{array}{c}\text { Support from social } \\
\text { environment is a need }\end{array}$ & $\bullet$ & $\begin{array}{l}\text { Support from family } \\
\text { Support from organization }\end{array}$ \\
\hline $\begin{array}{c}\text { Motherhood is demanding } \\
\text { for an academic woman }\end{array}$ & $\bullet$ & Keep the balance \\
& $\bullet$ & $\begin{array}{l}\text { Heavy workload } \\
\text { A big mission: Social gender role }\end{array}$ \\
\hline
\end{tabular}

\section{Theme 1: Support from social environment is a need}

As being a mother can be both an exciting and exhausting process for a woman, the participants of this study emphasized that support from their social environment was a need starting from the pregnancy. However, they divided the support from social environment into two different groups as support from family and support from organization.

Support from family. The academic women in this study mentioned that they got support from their family before and after giving birth to their children and, this helped them a lot. The support was mostly from their parents, and support from their spouse was also quite important for them. Support from family helped them survive in terms of academy, and also of motherhood.

\footnotetext{
Being a mother puts you in a difficult process. I got help from my husband and my parents to cope with this difficulty. (A1)
} 
After becoming a mother, I didn't have to make a choice between my career and my family life. This happened thanks to my husband's and my parents' support. They took the responsibility for baby care as much as I did, and this helped me a lot. (A2)

The support from my parents was very important for me. My mother and father were always with me. I never had problems about babysitters, because I never needed one. When I gave birth, and when I turned back to my work, my parents were always there for me. (A4)

After my child was born, I studied for an exam to become an associate professor. Thanks to my husband and my mother, I could study very easily because they took care of my son while I was studying. (A3)

Support from organization. The second type of support which was seen equally important by the participants was support from organization. They said they did not get the sufficient support from the management of their faculty, and this made the adaptation process harder for them.

I got help from my administrators and co-workers in the limits of my legal rights. Sometimes I couldn't use my breast-feeding permission. (A2)

I got my maternity leave, but I had to turn back to work two months earlier since there was a need. My course-load was as much as my other colleagues. So my workload didn't get lower. (A1)

One of the participants even said that she was hindered by her department administrator after she became mother:

I didn't get any help from my administrators. On the contrary, I was hindered. I finished my PhD after my child was born. I gave a break for 2.5 years, and when I turned back to my work, I had the right to be tenured. However, my administrators didn't give that personnel cadre to $m e$, and they gave the cadre to another person. I thought this was a punishment. (A4)

\section{Theme 2: Motherhood is demanding for an academic woman}

The participant of this study talked about how difficult and demanding being an academic mother was. They had some responsibilities as a mother, and also as a woman due to their social gender role. They also added that the motherhood made them give a break to their academic life.

I feel myself regressed as an academician, since I had my maternity leave and this leave means being away from academic environment, it hinders you from attending congresses or workshops, and giving lectures, which also helps us improve ourselves. (A5)
After my son was born, I thought I would go on my studies, but then I understood that this was a dream. Until he was 5-month old, I couldn't do anything academic. Then I started to work, with the help of my mother and babysitter. (A6)

I had some flaws after my son's birth. During that time, I had to finish my PhD dissertation, so I turned back to study for my dissertation 3 days after I gave birth. I finished it, because it was a necessity. But then, I could turn back to my academic studies after 3 years. (A4)

Think about a baby that needs love and care from you, intensely. This is the reality for all mothers. For academic mothers, this reality means a demanding and challenging process in terms of work-life. I experienced this process, as well. (A1)

In addition to these, they emphasized they had so many works to do as an academician, first of which was giving lectures as many as other colleagues after the birth. As a result, academic mothers tried hard to keep the balance between their academic life and family roles. In the light of these findings, this theme has 3 sub-themes: keep the balance, heavy workload and a big mission: social gender role.

Keep the balance. The participants emphasized that they tried to keep the balance between their family roles and their academic life, because only then they could go on their life without ignoring either their families or their academic lives.

I am trying to carry on both motherhood and academic life in a balanced way. I am trying to invest in both as much as I do, because motherhood is very important and so is academic career. (A4)

I determine my priorities depending on the situation. Then, I put motherhood or my academic life in the first place, and spend my time and energy according to this decision. (A1)

I cannot say that I have a balance between them in my life. I believe it is not an easy thing to do so, by the way. I try to manage motherhood and academic life by changing my focus time to time. For example, if there is something urgent about work or if I try to finish my manuscript, I neglect my family and focus on my work. However if the situation is vice versa, then my focus is on my family and I neglect my academic life. (A2)

I believe I succeed to keep the balance between motherhood and my academic life. I do this by not bringing work at home if possible. If I have to study at home, then I do this when I am alone-for example late at night, when my son and my husband fall asleep. (A3)

One of the participants even said she had to plan her daily 
life and revise it frequently in order not to have any obstacles.

I must be planned about what I will do in a day. Also, I am trying to revise how I will use my time and energy. Because I have accepted the responsibilities I have in the family life, and the reality that I could spare little time for myself, I have to spend more energy on my work if I want to be successful in my academic career. (A5)

Despite the difficulties they have experienced, most of the academic women told that being mother was more important than academic career.

I am very happy that I had my daughter. It was the right decision for me to give birth to her, even though this made me give a break to my academic studies. I can still be an associate professor or I can finish my $P h D$ dissertation after 10 years, but becoming mother 10 years later would be impossible in terms of biological reasons. (A2)

My hardest decision was having another child. At first, I decided not to have a second child, but after a long time I changed my mind and decided to have my second child. It was a hard decision for me, because I was planning to prepare for the exam to become an associate professor. Now, I will give a break and raise my child, since this time I just want to focus on one thing and it will be becoming a mother. (A6)

Before I got pregnant, I knew that being a mother would affect my academic life deeply. I knew that I couldn't study for my PhD after the birth, because it meant going another city every week...It was impossible for a woman with a baby. Nevertheless, I chose to become a mother. I did the right thing and I never regret my decision. (A1)

Heavy workload. The academic women with pre-school age children that participated in this study agreed on that their workload was as heavy as that of their male colleagues, also as heavy as that of their female colleagues who were not mothers.

I didn't have any support from academy during my first days of motherhood. In the following years? No. But I never gave up my academic life. I tried to survive on my own. What did I do? I slept less, I studied more, never expected any help from anyone, tried to do my best. Unfortunately, my physical health was affected by this workload in a negative way. I felt more tired, more burnt-out. However, I pretended to be strong when others looked at me, because I had to be strong for my son, for my family and for myself. (A4)

Doing academic studies, criteria for becoming an associate professor require academic projects, partnership and studying hard. As a mother and a spouse, it is difficult to focus on them as a whole. So, I needed to do more work in a short time even though I seemed like I kept the balance. I gave lectures, I studied, I read articles, I took care of my husband and my child...but I did all of them in a rush, because my time was limited due to the workload. (A6)

A big mission: Social gender role. The academic women emphasized that they had a big mission in their life: their social gender role. Because of the characteristics of Turkish culture, they have so many responsibilities for the child and for their family. Some of the academic women compared themselves with their male colleagues and they labelled the male academics as "lucky".

I sometimes think that if I were a man, I would be a professor because they have more time compared to us. We live in Turkish society. We have responsibilities as a woman. When a man does something which is seen as "woman's work", he is thanked; because it is considered help. But as a woman, it is our main role. Responsibility is mostly on our shoulders. (A4)

Unfortunately I have to admit that being a man in academy is a big advantage. I, as a woman, always have to plan my time in order not to bring work at home, finish my work and spend time with my husband and child. If I were a man, I would stay at school and study. I would study 2 or 3 hours in two evenings, for example, if I were a man, I wouldn't have to think about what I would cook, didn't have to prepare the meal and pick my son from school. Also going to a conference wouldn't be a problem for me. I would easily broaden my academic environment. Men are lucky in terms of these. (A6)

I certainly believe that my male colleagues are more advantageous. I have my social environment's support with me, but my responsibilities in family life and in social life are much more than my male colleagues'. (A5)

\section{Discussion}

With this study, the researchers aimed to find out how academic mothers with pre-school age children survive in academia from pregnancy through all the various stages of parenting and motherhood. The data from interviews with six academic mothers from a state university led to two main themes: Support from social environment is a need and Motherhood is demanding for an academic woman. In this section, the significance of the findings will be mentioned under these two themes. 


\subsection{Support from Social Environment is a Need}

Academic mothers of this study emphasized the importance of support from their social environment. All of the six mothers said that they managed to survive in academic life with the help of their parents, especially their mothers, together with their husbands. Many of the academic women with pre-school age children who participated in this study said they did not have to deal with baby-sitters because their mothers were always there for them. These findings are similar to Cindoğlu and Toktaş's [3] study. In their study, Cindoğlu and Toktaş [3] tried to analyse the empowerment and resistance strategies used by working women in Turkey who graduated from Girls' Institutes. The participants of that study said that their families had been supportive to them to attain education and gain their economic independence. Within their families, their mothers were very supportive and did their best to send their daughter to school, and also supported them through their professional life [3]. In this study, it was found out that the most supportive parent was mostly mothers.

Women academics in this study mostly did not get any support from their organizations and their administrators. One of the participants said she did not get any support; she was hindered by her administrator and, could not take her academic cadre even though she gained the right for it. These findings are similar to previous studies' findings $[13,8,9]$. Hammond [13] said that academic women faced the obstacles against their academic career which were brought to them by academic men, because it was thought that the university was a "man's world" where the old boy network existed, perhaps still exists [9]. Humm [14] stated that male co-workers of academic women defended the idea that men and women were equal, because their salaries were the same; however equal opportunity did not mean equal salary, but it meant equal value and opportunities for academic studies and promotion. On the other hand, Ledwith and Menfredi [8] emphasized that there were homo-social male territories in universities, and women were chosen as members of unimportant committees, were not taken seriously as academics if they were mothers; and the academic men provided poor references for academic women, which could affect their promotion negatively. Humm [14] suggested that women in academy were exposed to "sharp attacks", such as misuse of their efforts, isolation, lack of security for sexist behaviours; and all of these factors caused academic women to try to survive in an intellectual environment with negative equity and low morale ruled by male co-workers. Ledwith and Menfredi [8] also mentioned that because of this male dominant structure of academy; even if academic women become administrators, they did not support their female colleagues in order to survive in academy.

\subsection{Motherhood is Demanding for an Academic Woman}

Academic women with pre-school age children who participated in this study emphasized that motherhood and academic life were difficult and demanding for them. They said that it was hard for them to keep the balance between their academic work and family life, and to do this, they studied quite hard when compared to their male colleagues. They also mentioned that as a woman, the relationship with relatives, housework, and babysitting were all their responsibilities. This point of view of the academic women may be interpreted as the internalization of gender roles attributes. The studies on gender roles can be evaluated as being supportive to this idea $[15,16,17]$.

Sancar [16] claimed that the primitive societies' characteristics affected contemporary social gender roles, because in primitive societies men went out the cave and hunted, and women got pregnant and they gave birth to children and took care of them. The effects of these conditions are visible in today's daily life. House errands, growing children and taking care of the house are perceived as the women's responsibilities whether she works or not. Günay and Bener [17] suggest that there is a common conception that women are responsible for babysitting, house errands, taking care of elder people in the family in contemporary societies. Turkish societal structure show similar characteristics, too. When the studies conducted in Turkey are analysed, it is highly possible to see that working women highlight their social gender role responsibilities.

One of the studies on societal structures affecting social gender role in Turkey was conducted by Başarır and Sarı [2]. The study investigated women academics' perceptions regarding 'being a women academic' through metaphors. In their study the women academics saw themselves as individuals with multi-missions and responsibilities. The answers of academic women comprised of metaphors like 'octopus' and 'cloned human', because they believed academic women had to organize more than one work at the same time like being a housewife, an academic, a teacher, and an administrator at the same time [2]. These findings are compliant with this study's findings, since in this study, academic women emphasized that they had so many responsibilities, so much work to do both in academic and family life. In addition to this, they also asserted that there are some expectations from the woman in family life in Turkish society and they need to behave and organize their life according to these roles. Because of these roles and expectations from women, they believe they cannot work as productive as they want. Also they have mentioned that they see their male colleagues as lucky since they do not have the same responsibilities with them.

In Başarır and Sarı's study [2] the academic women thought that they were like 'warriors' and 'supermen' because they had so many roles and responsibilities in their private life and academic life; they did not receive any support from anyone; and they struggled to overcome the obstacles they faced in the society. These findings are also similar to this study's findings. Academic women with pre-school age children thought they had a heavy workload that included all the works mentioned above. 
In the light of these findings, it is highly possible to suggest that the academic life should be eased for women with pre-school age children. There should be some regulations for this as the finding of these and previous researches suggest $[2,3]$, these rules make the life for women with children harder. Acker [18] claimed that employers tend to recruit men in order to avoid some problems about women related to their family life roles. Moreover, Acker [18] mentioned that employers have bias against women as they are good at caring and they are gentle, but men are good at using machines and tools. Unfortunately, these beliefs affect women's professional life negatively.

Within the light of this information and the findings of the study, it would be fair to suggest that working life should be made easier for women. Organizations should have some pro-women rules in order to achieve this. There should be some practices for positive discrimination. For example, women who are married or who have children should have the chance of coming to work later than men, or leave the work earlier than men if they need to. When it comes to universities, where this study was conducted, it can be suggested that administrators in universities have the primary role. They should be more understanding for women with pre-school age children and should be supportive to them and make them feel this support. By maintaining the justice, the administrators can make the conditions easy for academic women, for example they can give breastfeeding break to them easily and the programs can be adjusted according to this. By doing these, administrators can make the life of academic women with pre-school age children better, and this will surely increase academic motivation and success of these women.

This study provides modest insights into a crucial situation but the findings of this study are limited to the setting and the participants in the study. However, the findings of the current study may serve a good basis for future studies. In order to see whether the same considerations are shared at large, quantitative studies can be designed to include female academicians in Turkey or globally. Finally, it is noteworthy to state that the findings of the current research can help practitioners - mostly those who are in administrative positions in educational institutions- understand the internal and external factors that disturb and negatively affect female employees in academic circles.

\section{REFERENCES}

[1] World Health Organization (WHO). Online available from http://www.who.int/gender/whatisgender/en/, 2014.

[2] Başarır, F., Sarı, M. Kadın akademisyenlerin "kadın akademisyen olma"ya ilişkin algılarının metaforlar yoluyla incelenmesi, Yükseköğretim ve Bilim Dergisi, Vol.5, No.1, 41-51, 2015 .
[3] Cindoğlu, D, Toktaş, S. Empowerment and resistance strategies of working women in Turkey: The case of 1960-1970 graduates of the Girls' Institutes, The European Journal of Women's Studies,Vol.9, No.1, 31-48, 2002.

[4] Comer, D.R., Stites-Doe, S. Antecedents and consequences of faculty women's academic-parental role balancing, Journal of Family and Economic Issues, Vol. 27, No. 3, 495-512, 2006.

[5] Ergöl, Ş., Koç, G., Eroğlu, K., Taşkın, L. Türkiye'de kadın araştırma görevlilerinin ev ve iş yaşamlarında karşılaştıkları güçlükler, Yükseköğretim ve Bilim Dergisi, Vol. 2, No. 1, 43-49, 2012

[6] Edgren, M. (1998). Role of Ministries of Education. Paper presented at European Conference of Gender Equality, University of Helsinki, 1998.

[7] Bett, M. Independent Review of Higher Education Pay and Conditions: Report of a Committee Chaired by Sir Michael Bett. London: Stationery Office, 1999.

[8] Ledwith, S., Menfredi, S. Balancing gender in higher education: A study of experience women in a 'new' UK university. The European Journal of Women's Studies, Vol. 7, 7-33, 2000.

[9] Bagilhole, B., Goode, J. The contradiction of the myth of individual merit, and the reality of a patriarchal support system in academic careers: A feminist investigation. The European Journal of Women's Studies, Vol. 8, No. 2, 161-180, 2001.

[10] YOK. Öğretim Elemanları Sayıları Özet Tablosu. Online available from

https://istatistik.yok.gov.tr/yuksekogretimIstatistikleri/2016/2 016 T2.pdf., 2016.

[11] Creswell, J. W. Qualitative Inquiry and Research Design: Choosing Among Five Approaches, Sage Publications, California, 2007.

[12] Baxter, P., Jack, S. Qualitative case study methodology: Study design and implementation for novice researchers, The Qualitative Report, Vol. 13, No. 4, 544-559, 2008.

[13] Hammond, V. Cultural change and equal opportunities: Learning from opportunity, Equal Opportunities Review 75 (September/ October), 14-22, 1997.

[14] Humm, M. Equal opportunities and higher education. In Breaking boundaries: Women in higher education (Ed. Morley,L., Walsh, V.), 102-109, 1996.

[15] Dedeoğlu, S. Toplumsal cinsiyet roller açısından Türkiye'de aile ve kadın emeği, Toplum ve Bilim, Vol. 86, 135-170, 2000.

[16] Sancar, S. (2009). Erkeklik: İmkansız İktidar, Metis Yayınları, İstanbul, 175-176, 2009.

[17] Günay, G.., Bener, Ö. Kadınların toplumsal cinsiyet rolleri çerçevesinde aile içi yaşamı algılama biçimleri, Türkiye Sosyal Araştırmalar Dergisi, Vol. 15, No. 3, 157-171, 2011.

[18] Acker, J. Gendered organizations and intersectionality: Problems and possibilities. Equality, Diversity and Inclusion: An International Journal, Vol. 31, No. 3, 214-224, 2012. 